\title{
Analisis Potensi Penerimaan Pajak Daerah Dan Retribusi Daerah Kota Pematangsiantar
}

\author{
Asmawati Halilah Damanik ${ }^{1}$ \\ Sekolah Tinggi Akuntansi dan Manajemen \\ Indonesia \\ asmawatidamanik@gmail.com
}

\author{
Nora Januarti Panjaitan ${ }^{3}$ \\ Politeknik Bisnis Indonesia \\ nvanzaithan@gmail.com
}

\author{
Amran Saragih ${ }^{2}$ \\ Sekolah Tinggi Akuntansi dan Manajemen \\ Indonesia \\ amransaragih21026@gmail.com \\ Christina Kumala ${ }^{4}$ \\ Sekolah Tinggi kuntansi dan Manajemen \\ Indonesia \\ c.kumala11@gmail.com
}

\begin{abstract}
Local tax revenues and levies, especially in the city of Pematangsiantar, have not been fully implemented effectively and optimally because one of them is the regulations on tax collection and sanctions for violations that have not been fully enforced. As a developing area, the city of Pematangsiantar should manage sources of income that can be used in development to improve public services in a real and sustainable manner. The potential that exists in Pematangsiantar City must be managed optimally, seen from the number of restaurants and hotels in Pematangsiantar City, an indication that if the government is serious in handling taxes, the revenue that will become Pematangsiantar City's income will increase. However, it is estimated that the main problems in the study of tax potential are not insignificant, mainly related to administrative performance as well as taxpayer compliance. For this reason, a solution is needed how to make efforts to increase tax revenue.
\end{abstract}

Keywords : developing, effectively

\section{PENDAHULUAN}

Dalam penyelenggaraan pemerintah daerah diarahkan untuk terwujudnya kesejahteraan masyarakat melalui peningkatan pelayanan, pemberdayaan, dan peran serta masyarakat, serta peningkatan daya saing daerah dengan memperhatikan Prinsip demokrasi, pemerataan, keadilan, dan kekhasan suatu daerah dalam sistem negara kesatuan Republik Indonesia. Efisiensi dan efektivitas penyelenggaraan pemerintahan daerah perlu ditingkatkan dengan lebih memperhatikan aspek-aspek hubungan antara pemerintah pusat dengan daerah dan antar daerah, potensi dan keanekaragaman daerah, serta peluang dan tantangan persaingan global dalam kesatuan sistem penyelenggaraan pemerintahan negara.

Menurut Undang-undang No. 32 Tahun 2004 tentang pemerintahan daerah dan diubah dengan Undang-undang No. 23 Tahun 2014 karena sudah tidak sesuai dengan perkembangan keadaan, ketatanegaraan, dan tuntutan penyelenggaraan pemerintah daerah sehingga perlu diganti.

Di Indonesia pajak merupakan sumber pendapatan yang bagi negara untuk kemudian disalurkan dalam pembenahan infrastruktur, pelayanan publik yang manfaatnya akan dirasakan oleh masyarakat luas. Era otonomi di Indonesia saat ini perlu melakukan kreasi dalam mencari sumber penerimaan yang dapat membiayai 
pengeluaran pemerintah daerah dalam rangka menyelenggarakan pemerintahan dan pembangunan. Dengan demikian pemerintah daerah tidak hanya dituntut untuk mampu menyelenggarakan pemerintahan, pembangunan, dan pelayanan kepada masyarakat, akan tetapi secara finansial mampu untuk membiayai segala kebutuhannya.

Dalam melaksanakan otonomi daerah, setiap daerah yang ada diseluruh Indonesia dituntut untuk selalu berupaya meningkatkan sumber Pendapatan Asli Daerah (PAD) yang mencerminkan kemandirian daerah dalam mengelola keuangannya. Upaya peningkatan pendapatan asli daerah dapat dilakukan dengan cara terus berusaha mencari dan menggali sumber-sumber baru, pendapatan baru, dan tidak lupa untuk terus meningkatkan efisiensi sumber daya dan saranan yang terbatas serta meningkatkan efektivitas dari kegiatan yang telah ada. Dalam permasalahan yang sering kali terlihat ialah penerimaan dari sektor pajak dan retribusi daerah tidak terlalu efektif sehingga sering kali daerah bergantung dari dana perimbangan yang di alokasikan pemerintah pusat untuk daerah.

Penerimaan pajak daerah dan retribusi daerah khususnya di kota Pematangsiantar belum sepenuhya dilakukan secara efektif dan optimal dikarenakan salah satunya ialah regulasi dalam pemungutan pajak serta sanksi-sanksi pelanggaran belum diberlakukan secara keseluruhan. Sebagai daerah yang berkembang kota Pematangsiantar sudah seharusnya mengelolah sumber-sumber pendapatan yang dapat digunakan dalam pembangunan guna meningkatkan pelayanan publik secara nyata dan berkesinambungan. Potensi yang ada di Kota Pematangsiantar harus di kelola secara maksimal dilihat dari banyaknya restoran dan hotel yang berada di Kota Pematangsiantar merupakan indikasi jika pemerintah serius dalam penanganan pajak maka penerimaan yang akan menjadi pendapatan Kota Pematangsiantar akan meningkat. Namun demikian, permasalahan utama dalam kajian potensi pajak diperkirakan tidak sedikit, terutama berkaitan dengan kinerja pengadministrasian maupun juga berkaitan dengan kepatuhan wajib pajak. Untuk itu dibutuhkan solusi bagaimana upaya yang harus dilakukan dalam meningkatkan penerimaan pajak.

\section{KAJIAN LITERATUR \\ Pengertian Pajak}

Menurut Perda Kota

Pematangsiantar Nomor 10 Tahun 2014 tentang Perubahan Kedua atas Peraturan Daerah Kota Pematangsiantar Nomor 6 Tahun 2011 Tentang Pajak Daerah. Pajak Daerah yang selanjutnya disebut Pajak adalah kontribusi wajib kepada Daerah yang terutang oleh orang pribadi atau badan yang bersifat memaksa berdasarkan UndangUndang, dengan tidak mendapatkan imbalan secara langsung dan digunakan untuk keperluan Daerah bagi sebesar-besarnya kemakmuran rakyat.

Dalam buku Mardiasmo yang berjudul Perpajakan (2013) Menurut Prof. Dr. Rochmat Soemitro, SH. Pajak adalah iuran rakyat kepada kas negara berdasarkan undang-undang (yang dapat dipaksakan) dengan tiada mendapat jasa timbal (kontraprestasi) yang langsung dapat ditunjukkan dan yang digunakan untuk membayar pengeluaran umum.

Menurut Sari (2013) Pajak merupakan iuran dari masyarakat kepada Negara yang terutang dan dapat dipaksakan berdasarkan undang-undang yang berlaku secara umum.

\section{Pengertian Pajak Daerah}

Dasar hukum pemungutan pajak daerah dan retribusi daerah adalah UndangUndang Nomor 28 Tahun 2009 tentang Pajak Daerah dan Retribusi Daerah. Dalam Undang-Undang tersebut Pasal 1 ayat (10) menjelaskan bahwa: Pajak daerah, yang selanjutnya disebut pajak, adalah kontribusi wajib kepada daerah yang terutang oleh orang pribadi atau badan yang bersifat memaksa berdasarkan Undang-undang, dengan tidak mendapatkan imbalan secara langsung dan digunakan untuk keperluan 
daerah bagi sebesar-besarnya kemakmuran rakyat.

Menurut Mardiasmo (2016) Pajak Daerah memiliki arti hampir sama, yaitu pajak dipungut oleh daerah berdasarkan peraturan yang telah ditetapkan oleh daerah untuk kepentingan dan kebutuhan pemerintah daerah.

\section{METODELOGI PENELITIAN Jenis Penelitian}

Jenis penelitian yang digunakan dalam melakukan penelitian ini adalah pendekatan kuantitatif, menurut Sugiyono (2018:07) metode kuantitatif dinamakan metode tradisional, karena metode ini sudah cukup lama digunakan sehingga sudah mentradisi sebagai metode untuk penelitian. Metode ini disebut sebagai metode positivistik karena berlandaskan pada filsafat positivisme.

Metode ini sebagai metode ilmiah / scientific karena telah memenuhi kaidahkaidah ilmiah yaitu konkrit/empiris, obyektif, terukur, rasional dan sistematis. Metode ini juga disebut metode discovery, karena dengan metode ini dapat ditemukan dan dikembangkan berbagai iptek baru. Metode ini disebut kuantitaif karena data penelitian berupa angka-angka dan analisis menggunakan statistikdan akurat mengenai fakta-fakta yang ada, sifat dan karakter, serta hubungan antara fenomena yang sedang diteliti, yaitu analisa harga pokok penjualan untuk menentukan laba penjualan.

Penelitian ini dimaksudkan juga untuk menguji hipotesa atau teori, tetapi hanya merupakan pengamatan dan penelitian yang memberikan penjelasan terhadap suatu keadan kemudian berusaha memberikan kesimpulan atau pengamatan tersebut (Yin,2011;1).

Jenis dan sumber data :

1. Data Primer

a. Hasil observasi penulis terhadap UD Mutiara Rambung Merah

b. Hasil wawancara dengan pihak terkait. c. Data Sekunder
a.Buku-buku ilmiah yang berhubungan dengan Harga Pokok Penjualan
b.Jurnal-Jurnal yang di kutip dari wibside
c. Laporan hasil penjualan dari UD Mutiara

\section{Teknik Pengumpulan Data}

Teknik pengumpulan data yang digunakan dalam penelitian ini adalah sebagai berikut:

\section{Wawancara}

Dalam penelitian ini, wawancara yang dimaksud untuk memperoleh data secara subjektif tentang penerimaan Pendapatan Asli Daerah tahun 20152018 pada Badan Pengelola Keuangan Daerah Kota Pematangsiantar.

\section{Studi Dokumentasi}

Yaitu memperoleh atau mengumpulkan dokumen-dokumen atau berkas. Metode ini dilakukan untuk mengumpulkan data Pajak Daerah dan Retribusi Daerah Kota Pematangsiantar tahun 2015-2018.

3. Studi Kepustakaan

Dalam penelitian ini, data yang digunakan merupakan data-data sekunder yang diperoleh dari BPKD (Badan Pengelola Keuangan Daerah). Yaitu berupa informasi mengenai Pajak Daerah dan Retribusi Daerah selama periode 2015-2018.

\section{Teknik Analisis}

Teknik analisis data yang digunakan dalam penelitian ini adalah teknik analisis deskriptif kuantitatif, teknik tersebut digunakan untuk menganalisis tingkat kontribusi, pertumbuhan, dan efektivitas sehingga dapat digunakan untuk menganalisis potensi dari masing-masing sektor Pajak dan Retribusi Daerah Kota Pematangsiantar tahun 2015-2018. Adapun analisis yang digunakan yaitu: Rasio Efektivitas, Analisis Pertumbuhan dan Analisis Kontribusi. 


\section{PEMBAHASAN}

\section{Analisis Efektivitas}

1. Efektivitas Pajak Daerah $=$ $\frac{\text { Realisasi Penerimaan Pajak Daerah }}{\text { Target Penerimaan Pajak Daerah }} \times 100 \%$

a. Efektivitas Tahun $2016=$ $\frac{35.735 .129 .177,34}{36.330 .000 .000} \times 100 \%=98,36 \%$

Dari perhitungan di atas diperoleh tingkat efektivitas Pajak Daerah di Kota Pematangsiantar tahun 2016 sebesar 98,36\%. Dapat dikatakan bahwa realisasi penerimaan pajak daerah kurang mencapai target pajak daerah yang sudah ditentukan yaitu sebesar $1,64 \%$.

b. Efektivitas Tahun $2017=$ $\frac{46.253 .296 .639,20}{39.730 .000 .000} \times 100 \%=116,42 \%$

Dari perhitungan diatas diperoleh tingkat efektivitas Pajak Daerah di Kota Pematangsiantar pada tahun 2017 sebesar 116,42\%. Dapat dikatakan bahwa realisasi penerimaan pajak daerah melebihi target pajak daerah yang sudah ditentukan yaitu sebesar 16,42\%

c. Efektivitas Tahun $2018=$ $\frac{46.460 .214 .440,08}{40.100 .000 .000} \times 100 \%=115,86 \%$

Dari perhitungan di atas diperoleh tingkat efektivitas Pajak Daerah di Kota Pematangsiantar tahun 2018 sebesar $115,86 \%$. Dapat dikatakan bahwa realisasi penerimaan pajak hotel melebihi target pajak hotel yang sudah ditentukan yaitu sebesar $15,86 \%$.

Tabel Efektivitas Pajak Daerah Kota

Pematangsiantar Tahun 2016-2018

\begin{tabular}{|c|c|c|c|c|}
\hline $\begin{array}{c}\text { Pajak } \\
\text { Daerah }\end{array}$ & Realisasi (Rp) & Target (Rp) & $\begin{array}{c}\text { Presentase } \\
\text { Efektivitas (\%) }\end{array}$ & Keterangan \\
\hline Tahun 2016 & $35.735 .129 .177,34$ & 36.330 .000 .000 & $98,36 \%$ & Efektif \\
\hline Tahun 2017 & $46.253 .296 .639,20$ & 39.730 .000 .000 & $116,42 \%$ & Sangat Efektif \\
\hline Tahun 2018 & $46.460 .214 .440,08$ & 40.100 .000 .000 & $115,86 \%$ & Sangat Efektif \\
\hline \multicolumn{3}{|c|}{ Rata-rata } & $110,21 \%$ & Sangat Efektif \\
\hline
\end{tabular}

Sumber: Data Diolah

Berdasarkan tabel ini dapat dilihat bahwa Efektivitas Pajak Daerah dalam kurun waktu 2016-2018 mengalami peningkatan maupun penurunan. Pada tahun
2016 Efektivitas Pajak Daerah sebesar 98,36\%. Berdasarkan Kriteria Efektivitas Pajak (Kepmendagri No. 690.900.327) tingkat Efektivitas Pajak Daerah pada tahun 2016 termasuk dalam kriteria Efektif.

Pada tahun 2017 Efektivitas Pajak Daerah mengalami peningkatan dengan Efektivitas Pajak Daerah sebesar 116,42\%. Berdasarkan Kriteria Efektivitas (Kepmendagri No. 690.900.327), tingkat Efektivitas Pajak Daerah pada tahun 2017 termasuk dalam kriteria Sangat Efektif.

Pada tahun 2018 Efektivitas Pajak Daerah mengalami penurunan sebesar 0,56\% dengan Efektivitas Pajak Daerah sebesar 115,86\%. Berdasarkan Kriteria Efektivitas (Kepmendagri No. 690.900.327), tingkat Efektivitas Pajak Hotel tahun 2018 termasuk dalam kriteria Sangat Efektif.

Rata-rata tingkat Efektivitas Pajak Daerah pada tahun 2016-2018 sebesar 110,21\%. Berdasarkan Kriteria Efektivitas (Kepmendagri No. 690.900.327), tingkat efektivitas Pajak Daerah pada tahun 20162018 sudah termasuk dalam kriteria Sangat Efektif. Meskipun pada tahun 2016 Efektivitas Pajak Daerah masih kurang dari $100 \%$ yang disebabkan oleh kurangnya sosialisasi pemerintah Kota Pematangsiantar kepada publik akan pentingnya pembayaran pajak serta Pemerintah Kota Pematangsiantar harus terus berupaya untuk lebih meningkatkan pemungutan pajak daerah untuk kedepannya.

2. Efektivitas Retribusi Daerah $=$ $\frac{\text { Realisasi Penerimaan Retribusi Daerah }}{\text { Target Penerimaan Retribusi Daerah }} \times 100 \%$

a. Efektivitas Tahun $2016=$ $\frac{7.696 .959 .900}{9.728 .628 .000} x 100 \%=79,12 \%$

Dari perhitungan di atas diperoleh tingkat efektivitas Retribusi Daerah di Kota Pematangsiantar tahun 2016 sebesar 79,12\%. Dapat dikatakan bahwa realisasi penerimaan retribusi daerah tidak mencapai target retribusi daerah yang sudah ditentukan yaitu sebesar $20,88 \%$. 
b. Efektivitas Tahun $2017=$ $\frac{6.716 .916 .980}{7.754 .773 .000} \times 100 \%=86,62 \%$

Dari perhitungan di atas diperoleh tingkat efektivitas Retribusi di Kota Pematangsiantar tahun 2017 sebesar 86,62\%. Dapat dikatakan bahwa realisasi penerimaan retribusi daerah tidak mencapai target retribusi daerah yang sudah ditentukan yaitu sebesar 13,38\% .

c. Efektivitas Tahun $2018=$ $\frac{10.996 .225 .560}{13.299 .773 .000} \times 100 \%=82,68 \%$

Dari perhitungan di atas diperoleh tingkat efektivitas Retribusi Daerah di Kota Pematangsiantar tahun 2016 sebesar 82,68\%. Dapat dikatakan bahwa realisasi. penerimaan retribusi daerah tidak mencapai target retribusi daerah yang sudah ditentukan yaitu sebesar 17,32\%.

Tabel Efektivitas Retribusi Daerah Kota

Pematangsiantar Tahun 2016-2018

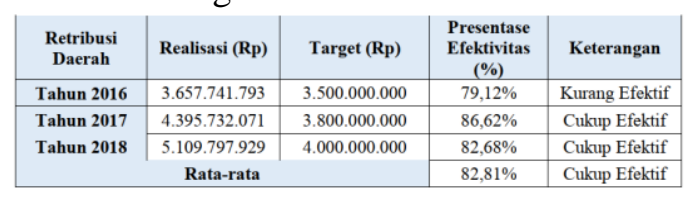

Sumber: Data Diolah

Berdasarkan tabel 4.6, dapat dilihat bahwa Efektivitas Retribusi Daerah dalam kurun waktu 2016-2018 mengalami peningkatan dan penurunan. Pada tahun 2016 Efektivitas Retribusi Daerah sebesar 79,12\%. Berdasarkan Kriteria Efektivitas Pajak (Kepmendagri No. 690.900.327) tingkat Efektivitas Retribusi Daerah pada tahun 2016 termasuk dalam kriteria Kurang Efektif.

Pada tahun 2017 Efektivitas Retribusi Daerah mengalami peningkatan sebesar 7,5\% dengan Efektivitas Retribusi Daerah sebesar 86,62\%. Berdasarkan Kriteria Efektivitas (Kepmendagri No. 690.900.327), tingkat Efektivitas Restribusi Daerah pada tahun 2017 termasuk dalam kriteria Cukup Efektif.

Pada tahun 2018 Efektivitas Retribusi Daerah mengalami penurunan sebesar
3,94\% dengan Efektivitas Retribusi Daerah sebesar 82,68\%. Berdasarkan Kriteria Efektivitas (Kepmendagri No. 690.900.327), tingkat Efektivitas Retribusi Daerah tahun 2018 termasuk dalam kriteria Cukup Efektif.

Rata-rata tingkat Efektivitas Retribusi Daerah pada tahun 2016-2018 sebesar 82,81\%. Berdasarkan Kriteria Efektivitas (Kepmendagri No. 690.900.327), tingkat efektivitas retribusi daerah pada tahun 20162018 termasuk dalam kriteria Cukup Efektif.

\section{Laju Pertumbuhan}

1. Laju Pertumbuhan Pajak Daerah $=$

$$
G X=\frac{X t-X(t-1)}{X(t-1)} x 100 \%
$$

a. Tahun 2016

$$
\begin{aligned}
& G(2016) \\
& =\frac{35.735 .129 .177,34-31.105 .131 .475,84}{31.105 .131 .475,84} \times 100 \% \\
& G(2016) \\
& =\frac{4.629 .997 .701,5}{31.105 .131 .475,84} \times 100 \% \\
& G(2016)=14,88 \%
\end{aligned}
$$

Dari perhitungan di atas diperoleh laju pertumbuhan Pajak Daerah Kota Pematangsiantar tahun 2016 sebesar $14,88 \%$. Hal ini berarti bahwa diperoleh kenaikan penerimaan pajak daerah sebesar $14,88 \%$.

$$
\begin{aligned}
& \text { b. Tahun } 2017 \\
& \text { G(2017) } \\
& =\frac{46 \cdot 253 \cdot 296 \cdot 639,20-35 \cdot 735 \cdot 129 \cdot 177,34}{35 \cdot 735 \cdot 129 \cdot 177,34} \times 100 \% \\
& \text { G(2017) } \\
& =\frac{10.518 .167 .462}{35.735 .129 .177,34} \times 100 \% \\
& G(2017)=29,43 \% \\
& \text { Dari perhitungan di atas diperoleh } \\
& \text { laju pertumbuhan Pajak Daerah } \\
& \text { Kota Pematangsiantar tahun } 2017 \\
& \text { sebesar } 29,43 \% \text {. Hal ini berarti } \\
& \text { bahwa diperoleh kenaikan } \\
& \text { penerimaan pajak daerah sebesar } \\
& 29,43 \% \text {. }
\end{aligned}
$$


c. Tahun 2018

$$
\begin{aligned}
& G(2018) \\
& =\frac{46.460 .214 .440,08-46.253 .296 .639,20}{46.253 .296 .639,20} \\
& \begin{array}{l}
G(2018) \\
=\frac{206.917 .800,88}{2.179 .811 .557,20}
\end{array} \times 100 \% \\
& G(2018)=9,50 \%
\end{aligned}
$$

Dari perhitungan di atas diperoleh laju pertumbuhan Pajak Daerah Kota Pematangsiantar tahun 2018 sebesar 9,50\%. Hal ini berarti bahwa diperoleh kenaikan penerimaan pajak daerah sebesar $9,50 \%$.

Tabel Laju Pertumbuhan Pajak Daerah Kota Pematangsiantar Tahun 2016-2018

\begin{tabular}{|c|c|c|c|} 
Pajak Daerah & Realisasi (Rp) & $\begin{array}{c}\text { Presentase Laju } \\
\text { Pertumbuhan } \\
(\%)\end{array}$ & Keterangan \\
\hline Tahun 2016 & $35.735 .129 .177,34$ & $14,88 \%$ & Tidak Berhasil \\
\hline \multirow{2}{*}{$\begin{array}{c}\text { Tahun } 2017 \\
\text { Tahun 2018 }\end{array}$} & $46.253 .296 .639,20$ & $29,43 \%$ & Tidak Berhasil \\
\cline { 2 - 4 } Rata-rata & $46.460 .214 .440,08$ & $9,50 \%$ & Tidak Berhasil \\
\cline { 2 - 4 } & $17,94 \%$ & Tidak Berhasil \\
\hline
\end{tabular}

\section{Sumber: Data Diolah}

Berdasarkan pada tabel 4.7, dapat dilihat bahwa Laju Pertumbuhan Pajak Daerah dalam kurun waktu 2016-2018 mengalami peningkatan dan penurunan. Pada tahun 2016 Laju Pertumbuhan Pajak Daerah sebesar $14,88 \%$. Berdasarkan kriteria Laju Pertumbuhan (Halim, 2012) tingkat Laju Pertumbuhan Pajak Daerah pada tahun 2016 termasuk dalam kriteria Tidak Berhasil.

Pada tahun 2017 Laju Pertumbuhan Pajak Daerah mengalami peningkatan sebesar $14,55 \%$ dengan Laju Pertumbuhan sebesar $29,43 \%$. Berdasarkan kriteria Laju Pertumbuhan (Halim, 2012) tingkat Laju Pertumbuhan Pajak Daerah pada tahun 2017 termasuk dalam kriteria Tidak Berhasil.

Pada tahun 2018 Laju Pertumbuhan Pajak Daerah mengalami penurunan sebesar 19,93\% dengan Laju Pertumbuhan sebesar 9,50\%. Berdasarkan kriteria Laju Pertumbuhan (Halim, 2012) tingkat Laju Pertumbuhan Pajak Daerah pada tahun 2018 termasuk dalam kriteria Tidak Berhasil.
Rata-rata tingkat Laju Pertumbuhan Pajak Daerah dari tahun 2016-2018 sebesar 17.94\%. Berdasarkan kriteria Laju Pertumbuhan (Halim, 2012) tingkat Laju Pertumbuhan Pajak Daerah pada tahun 2016-2018 termasuk dalam kriteria Tidak Berhasil. Dapat dikatakan bahwa Pemerintah Kota Pematangsiantar tidak berhasil dalam meningkatkan laju pertumbuhan pajak daerah, yang disebabkan karena masih kurangnya peran pemerintah Kota Pematangsiantar dalam memungut pajak daerah dan kurangnya pengawasan yang dilakukan oleh Pemerintah Kota Pematangsiantar.

2. Laju Pertumbuhan Retribusi Daerah $=$ $G X=\frac{X t-X(t-1)}{X(t-1)} x 100 \%$

a. Tahun 2016

G(2016)

$$
\begin{gathered}
=\frac{7.696 .959 .900-5.801 .756 .500}{5.801 .756 .500} \times 100 \% \\
G(2016)=\frac{1.895 .203 .400}{5.801 .756 .500} \times 100 \% \\
G(2016)=32,67 \%
\end{gathered}
$$

Dari perhitungan di atas diperoleh laju pertumbuhan Retribusi Daerah Kota Pematangsiantar tahun 2016 sebesar $32,67 \%$. Hal ini berarti bahwa diperoleh kenaikan penerimaan retribusi daerah sebesar $32,67 \%$.

b. Tahun 2017

G(2017)

$$
\begin{gathered}
=\frac{6.716 .916 .980-7.696 .959 .900}{7.696 .959 .900} \times 100 \% \\
G(2017)=\frac{-980.042 .920}{7.696 .959 .900} \times 100 \% \\
G(2017)=-12,73 \%
\end{gathered}
$$

Dari perhitungan di atas diperoleh laju pertumbuhan Retribusi Daerah Kota Pematangsiantar tahun 2017 sebesar $-12,73 \%$. Hal ini berarti bahwa diperoleh penurunan penerimaan retribusi daerah menjadi sebesar $12,73 \%$.

c. Tahun 2018 


$$
\begin{aligned}
& G(2018) \\
& =\frac{10.996 .225 .560-6.716 .916 .980}{6.716 .916 .980} \times 100 \% \\
& G(2018)=\frac{4.279 .308 .580}{6.716 .916 .980} \times 100 \% \\
& G(2018)=63,71 \% \\
& \text { Dari perhitungan di atas diperoleh } \\
& \text { laju pertumbuhan Retribusi Daerah } \\
& \text { Kota Pematangsiantar tahun 2016 } \\
& \text { sebesar 63,71\%. Hal ini berarti } \\
& \text { bahwa diperoleh kenaikan } \\
& \text { penerimaan retribusi daerah sebesar } \\
& \text { 63,71\%. }
\end{aligned}
$$

Tabel Laju Pertumbuhan Retribusi Daerah Kota Pematangsiantar Tahun 2016-2018

\begin{tabular}{|c|c|c|c|}
$\begin{array}{c}\text { Retribusi } \\
\text { Daerah }\end{array}$ & Realisasi (Rp) & $\begin{array}{c}\text { Presentase Laju } \\
\text { Pertumbuhan } \\
(\%)\end{array}$ & Keterangan \\
\hline Tahun 2016 & 7.696 .959 .900 & $32,67 \%$ & Kurang Berhasil \\
\hline $\begin{array}{c}\text { Tahun 2017 } \\
\text { Tahun 2018 }\end{array}$ & 6.716 .916 .980 & $-12,73 \%$ & Tidak Berhasil \\
\cline { 2 - 4 } Rata-rata & $63,71 \%$ & Cukup Berhasil \\
\cline { 2 - 4 } & $27,88 \%$ & Tidak Berhasil \\
\hline
\end{tabular}

Sumber: Data Diolah

Berdasarkan 4.6, dapat dilihat bahwa Laju Pertumbuhan Retribusi dalam kurun waktu 2016-2018 mengalami penurunan dan peningkatan. Pada tahun 2016 Laju Pertumbuhan Restribusi Daerah sebesar 32,67\%. Berdasarkan kriteria Laju Pertumbuhan (Halim 2012) tingkat Laju Pertumbuhan Retribusi Daerah pada tahun 2016 termasuk dalam kriteria Kurang Berhasil.

Pada tahun 2017 Laju Pertumbuhan Retribusi Daerah mengalami penurunan sebesar 45,4\% dengan Laju Pertumbuhan Retribusi Daerah sebesar -12,73\%. Berdasarkan kriteria Laju Pertumbuhan (Halim 2012) tingkat Laju Pertumbuhan Retribusi Daerah pada tahun 2017 termasuk dalam kriteria Tidak Berhasil. Penurunan ini disebabkan karena pada tahun 2017 retribusi daerah yang meliputi retribusi jasa umum; retribusi jasa usaha dan retribusi perizinan tertentu, realisasinya tidak ada yang mencapai target yang telah ditetapkan oleh Pemerintah Kota Pematangsiantar.

Pada tahun 2018 Laju Pertumbuhan Retribusi Daerah mengalami peningkatan sebesar 76,44\% dengan Laju Pertumbuhan
Retribusi Daerah sebesar 63,71\%. Berdasarakan kriteria Laju Pertumbuhan (Halim 2012) tingkat Laju Pertumbuhan Retribusi Daerah pada tahun 2018 termasuk dalam kriteria Cukup Berhasil.

Rata-rata tingkat Laju Pertumbuhan Retribusi Daerah pada tahun 2016-2018 sebesar 27,88\%. Berdasarkan kriteria Laju Pertumbuhan (Halim 2012) tingkat Laju Pertumbuhan Retribusi Daerah pada tahun 2016-2018 termasuk dalam kriteria Tidak Berhasil. Dapat dikatakan bahwa Pemerintah Kota Pematangsiantar tidak berhasil dalam meningkatkan laju pertumbuhan pajak Retribusi Daerah, yang disebabkan oleh masih kurangnya peran pemerintah Kota Pematangsiantar dalam memungut retribusi daerah serta kurangnya pengawasan yang dilakukan oleh Pemerintah Kota Pematangsiantar.

\section{Analisis Kontribusi}

1. Kontribusi Pajak Daerah = $\frac{\text { Realisasi Penerimaan Pajak Daerah }}{\text { Realisasi Pendapatan Asli Daerah }} \times 100 \%$

a. Tahun $2016=$ $\frac{35.735 .129 .177,34}{98.946 .205 .119,39} \times 100 \%=36,12 \%$ Dari perhitungan di atas diperoleh nilai Kontribusi Pajak Daerah Kota Pematangsiantar tahun 2016 sebesar $36,12 \%$. Dapat dikatakan bahwa penerimaan dari pajak daerah memberikan sumbangan sebesar 36,12\% terhadap Pendapatan Asli Daerah Kota Pematangsiantar.

b. Tahun $2017=$ $\frac{46.253 .296 .639,20}{105.445 .993 .204,23} \times 100 \%=43,86 \%$ Dari perhitungan di atas diperoleh nilai Kontribusi Pajak Daerah Kota Pematangsiantar tahun 2017 sebesar $43,86 \%$. Dapat dikatakan bahwa penerimaan dari pajak daerah memberikan sumbangan sebesar 43,86\% terhadap Pendapatan Asli Daerah Kota Pematangsiantar.

c. Tahun $2018=$ $\frac{46.460 .214 .440,08}{137.052 .839 .192,78} \times 100 \%=33,90 \%$

Dari perhitungan di atas diperoleh nilai Kontribusi Pajak Daerah Kota 
Pematangsiantar tahun 2018 sebesar $33,90 \%$. Dapat dikatakan bahwa penerimaan dari pajak daerah memberikan sumbangan sebesar 33,90\% terhadap Pendapatan Asli Daerah Kota Pematangsiantar.

Tabel Kontribusi Pajak Daerah Kota

Pematangsiantar Tahun 2016-2018

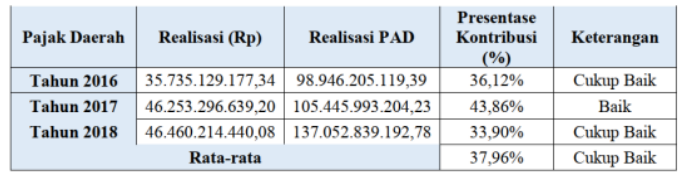

\section{Sumber: Data Diolah}

Berdasarkan pada tabel 4.7, dapat dilihat bahwa Kontribusi Pajak Daerah dalam kurun waktu 2016-2018 mengalami peningkatan dan penurunan. Pada tahun 2016 Kontribusi Pajak Daerah sebesar 36,12\%. Berdasarkan Kriteria Kontribusi Pajak (Kepmendagri No. 690.900.327), tingkat Kontribusi Pajak Daerah pada tahun 2016 termasuk dalam kriteria Cukup Baik.

Pada tahun 2017 mengalami peningkatan dengan Kontribusi Pajak Daerah sebesar 43,86\%. Berdasarkan Kriteria Kontribusi Pajak (Kepmendagri No. 690.900.327) tingkat Kontribusi Pajak Daerah pada tahun 2017 termasuk dalam kriteria Baik.

Pada tahun 2018 kembali mengalami penurunan sebesar 9,96\% dengan Kontribusi Pajak daerah sebesar 33,90\%. Berdasarkan Kriteria Kontribusi Pajak (Kepmendagri No. 690.900.327), tingkat Kontribusi Pajak Daerah pada tahun 2018 termasuk dalam kriteria Cukup Baik.

Rata-rata tingkat Kontribusi Pajak Daerah pada tahun 2016-2018 sebesar 37,96\%. Berdasarkan Kriteria Kontribusi Pajak (Kepmendagri No. 690.900.327), tingkat Kontribusi Pajak Daerah dari tahun 2016-2018 termasuk dalam kriteria Cukup Baik. Meskipun kriteria kontribusi pajak daerah cukup baik, Pemerintah Kota Pematangsiantar harus tetap lebih meningkatkan pemungutan pajak daerah agar menjadi lebih baik untuk kedepannya.
2. Kontribusi Retribusi Daerah $=$ $\frac{\text { Realisasi Penerimaan Retribusi Daerah }}{\text { Realisasi Pendapatan Asli Daerah }} \times 100 \%$

a. Tahun $2016=$ $\frac{7.696 .959 .900}{98.946 .205 .119,39} \times 100 \%=7,78 \%$

Dari perhitungan di atas diperoleh nilai Kontribusi Retribusi Daerah Kota Pematangsiantar tahun 2016 sebesar $7,78 \%$. Dapat dikatakan bahwa penerimaan dari retribusi daerah memberikan sumbangan sebesar 7,78\% terhadap Pendapatan Asli Daerah Kota Pematangsiantar.

b. Tahun $2017=$ $\frac{6.716 .916 .980}{105.445 .993 .204,23} \times 100 \%=6,37 \%$

Dari perhitungan di atas diperoleh nilai Kontribusi Retribusi Daerah Kota Pematangsiantar tahun 2017 sebesar $6,37 \%$. Dapat dikatakan bahwa penerimaan dari Retribusi Daerah memberikan sumbangan sebesar 6,37\% terhadap Pendapatan Asli Daerah Kota Pematangsiantar.

c. Tahun $2018=$ $\frac{10.996 .225 .560}{137.052 .839 .192,78} \times 100 \%=8,02 \%$ Dari perhitungan di atas diperoleh nilai Kontribusi Retribusi Daerah Kota Pematangsiantar tahun 2018 sebesar $8,02 \%$. Dapat dikatakan bahwa penerimaan dari retribusi daerah memberikan sumbangan sebesar 8,02\% terhadap Pendapatan Asli Daerah Kota Pematangsiantar.

Tabel Kontribusi Retribusi Daerah Kota

Pematangsiantar Tahun 2016-2018

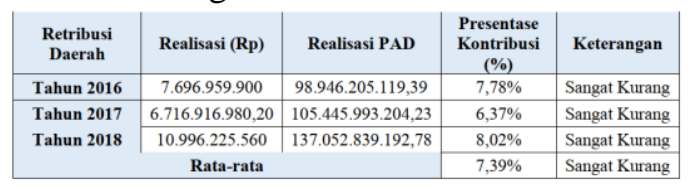

Sumber: Data Diolah

Berdasarkan pada tabel 4.8, dapat dilihat bahwa Kontribusi Retribusi Daerah dalam kurun waktu 2016-2018 mengalami peningkatan dan penurunan. Pada tahun 2016 Kontribusi Retribusi Daerah sebesar 
7,78\%. Berdasarkan Kriteria Kontribusi (Kepmendagri No. 690.900.327), tingkat Kontribusi Retribusi Daerah pada tahun 2016 termasuk dalam kriteria Sangat Kurang.

Pada tahun 2017 mengalami penurunan sebesar 1,41\% dengan Kontribusi Retribusi Daerah sebesar 6,37\%. Berdasarkan Kriteria Kontribusi (Kepmendagri No. 690.900.327), tingkat Kontribusi Retribusi Daerah pada tahun 2017 termasuk dalam kriteria Sangat Kurang.

Pada tahun 2018 mengalami peningkatan sebesar $1,65 \%$ dengan Kontribusi Retribusi Daerah sebesar 8,02\%. Berdasarkan Kriteria Kontribusi (Kepmendagri No. 690.900.327), tingkat Kontribusi Retribusi Daerah pada tahun 2018 termasuk dalam kriteria Sangat Kurang.

Rata-rata tingkat Kontribusi Retribusi Daerah pada tahun 2016-2018 sebesar $7,39 \%$. Berdasarkan Kriteria Kontribusi $\begin{array}{lll}\text { (Kepmendagri No. 690.900.327 } & \text { No. }\end{array}$ Kepmendagri No. 690.900.327), tingkat Kontribusi Retribusi Daerah dari tahun 2016-2018 termasuk dalam kriteria Sangat Kurang. Ini disebabkan karena bagian subsub retribusi daerah banyak yang tidak mencapai target, dan kurangnya pengawasan dari Pemerintah Kota Pematangsiantar dalam pemungutan retribusi daerah.

\subsubsection{Matriks Potensi}

\section{Matriks Potensi Pajak Daerah}

Tabel Matriks Potensi Pajak Daerah Kota Pematangsiantar 2016-2018

\begin{tabular}{|c|c|c|c|} 
Tahun & Kontribusi & $\begin{array}{c}\text { Laju } \\
\text { Pertumbuhan }\end{array}$ & Kriteria \\
\cline { 2 - 4 } $\mathbf{2 0 1 6}$ & Potensial & Positif & Prima \\
\cline { 2 - 4 } $\mathbf{2 0 1 7}$ & Potensial & Positif & Prima \\
\hline $\mathbf{2 0 1 8}$ & Potensial & Negatif & Potensial \\
\hline
\end{tabular}

Berdasarkan Tabel 4.9 dapat dilihat bahwa potensi pajak daerah Kota Pematangsiantar pada tahun 2016 dari matriks potensi masuk dalam kriteria Prima. Potensi pajak daerah Kota Pematangsiantar tahun 2016 masuk dalam kriteria Prima karena memberikan kontribusi yang besar (potensial) dengan tingkat pertumbuhan yang meningkat (positif).

Potensi pajak daerah Kota Pematangsiantar pada tahun 2017 dilihat dari matriks potensi masuk dalam kriteria Prima. Potensi pajak daerah Kota Pematangsiantar tahun 2017 masuk dalam kriteria Prima karena memberikan kontribusi yang besar (potensial) dengan tingkat pertumbuhan yang meningkat (positif).

Potensi pajak daerah Kota Pematangsiantar pada tahun 2018 dilihat dari matriks potensi masuk dalam kriteria Potensial. Potensi pajak daerah Kota Pematangsiantar tahun 2017 masuk dalam kriteria Potensial karena memberikan kontribusi yang besar (potensial) dengan tingkat pertumbuhan yang menurun (negatif).

\section{Matriks Potensi Retribusi Daerah}

Tabel Matriks Potensi Retribusi Daerah Kota Pematangsiantar 2016-2018

\begin{tabular}{|c|c|c|c|} 
Tahun & Kontribusi & $\begin{array}{c}\text { Laju } \\
\text { Pertumbuhan }\end{array}$ & Kriteria \\
\cline { 2 - 4 } & Tidak Potensial & Positif & Berkembang \\
\cline { 2 - 4 } $\mathbf{2 0 1 7}$ & Potensial & Negatif & Potensial \\
\hline $\mathbf{2 0 1 8}$ & Tidak Potensial & Positif & Berkembang \\
\hline
\end{tabular}

Sumber: Data Diolah

Berdasarkan Tabel 4.10 dapat dilihat bahwa potensi retribusi daerah Kota Pematangsiantar pada tahun 2016 dari matriks potensi masuk dalam kriteria Berkembang. Potensi retribusi daerah Kota Pematangsiantar tahun 2016 masuk dalam kriteria Berkembang, karena memberikan kontribusi yang rendah (tidak potensial) dengan tingkat pertumbuhan yang meningkat (positif).

Potensi retribusi daerah Kota Pematangsiantar pada tahun 2017 dilihat dari matriks potensi masuk dalam kriteria Potensial. Potensi retribusi daerah Kota Pematangsiantar tahun 2017 masuk dalam kriteria Potensial, karena memberikan kontribusi yang besar (potensial) dengan 
tingkat pertumbuhan yang menurun (negatif).

Potensi retribusi daerah Kota Pematangsiantar pada tahun 2018 dilihat dari matriks potensi masuk dalam kriteria Berkembang. Potensi retribusi daerah Kota Pematangsiantar tahun 2018 masuk dalam kriteria Berkembang, karena memberikan kontribusi yang rendah (tidak potensial) dengan tingkat pertumbuhan yang meningkat (positif).

\section{KESIMPULAN}

Berdasarkan hasil perhitungan dengan teknik analisis tingkat efektivitas, tingkat laju pertumbuhan, tingkat kontribusi dan potensi pajak daerah dan retribusi daerah Kota Pematangsiantar dalam kurun waktu 2016-2018, maka dapat disimpulkan bahwa:

1. Tingkat Efektivitas Pajak Daerah yang dimiliki Kota Pematangsiantar tahun 2016-2018 menunjukkan hasil rata-rata sebesar $110,21 \%$, dengan demikian tingkat efektivitas pajak daerah Kota Pematangsiantar termasuk dalam kriteria Sangat Efektif. Dan Tingkat Efektivitas Retribusi Daerah yang dimiliki Kota Pematangsiantar tahun 2016-2018 menunjukkan hasil rata-rata sebesar $82,81 \%$ dengan demikian tingkat efektivitas retribusi daerah Kota Pematangsiantar termasuk dalam kriteria Cukup Efektif. Jika dibandingkan dengan standart yang ditetapkan yaitu lebih dari $100 \%$ Sangat Efektif, 90\%-100\% Efektif, 80\%-90\% Cukup Efektif, dan 60\%-80\% Kurang Efektif.

2. Tingkat Laju Pertumbuhan Pajak Daerah yang dimiliki Kota Pematangsiantar tahun 2016-2018 menunjukkan hasil rata-rata sebesar $17,94 \%$ dengan demikian tingkat laju pertumbuhan pajak daerah Kota Pematangsiantar termasuk dalam kriteria Tidak Berhasil. Dan tingkat Laju Pertumbuhan yang dimiliki Kota Pematangsianntar tahun 2016-2018 menunjukkan hasil rata-rata sebesar
$27,88 \%$ dengan demikian tingat laju pertumbuhan retribusi daerah kota Pematangsiantar termasuk dalam kriteria Tidak Berhasil. Jika dibandingkan dengan standart yang ditetapkan yaitu 85\%-100\% Sangat Berhasil, 70\%-85\% Berhasil, 55\%-70\% Cukup Berhasil, 30\%-55\% Kurang Berhasil, dan kurang dari 30\% Tidak Berhasil.

3. Tingkat Kontribusi Pajak Daerah yang dimiliki Kota Pematangsiantar tahun 2016-2018 menunjukkan hasil rata-rata $37,96 \%$, dengan demikian tingkat kontribusi Pajak Daerah Kota Pematangsiantar termasuk dalam kriteria cukup baik. Dan tingkat kontribusi Retribusi Daerah yang dimiliki Kota Pematangsiantar tahun 2016-2018 menunjukkan hasil rata-rata $7,39 \%$, dengan demikian tingkat kontribusi Retribusi Daerah Kota Pematangsintar teermasuk dalam kriteria Sangat Kurang. Jika dibandingkan dengan standart yang ditetapkan yaitu 0,00\%-10\% Sangat kurang, 10,10\%-20\% Kurang, 20,10$30 \%$ Sedang, 30,10\%-40\% Cukup Baik, 40,10\%-50\% Baik, dan diatas 50\% Sangat Baik.

Potensi pajak daerah Kota Pematangsiantar tahun 2016-2018 dilihat dari matriks potensi masuk dalam kriteria Prima, karena memberikan kontribusi yang besar (potensial) dengan tingkat pertumbuhan yang meningkat (positif). Potensi retribusi daerah Kota Pematangsiantar tahun 2016-2018 dilihat dari matriks potensi masuk dalam kriteria berkembang, karena memberikan kontribusi yang rendah (tidak potensial) dengan tingkat pertumbuhan yang meningkat (positif).

\section{REFERENSI}

Juan Ng Eng dan Tri Wahyuni Ersa. (2012) Standar Akuntansi Keuangan Edisi II, (Terjemahan oleh Biro Bahasa Alkemis), Jakarta Selatan; Salemba Empat. 
Moloeng, J. Lexy (2012), Metodelogi Penelitian Kualitatif, PT. Remaja Rosdakarya Offset Bandung.

Mulyadi, ((1992), Akuntansi Biaya, Edisi 5, Cetakan, Penerbit STIE YKPN Jogyakarta

Rudianto (2012). Pengantar Akuntansi, Adaptasi IFRS , Penerbit Erlangga, Jakarta.

Sululing dan Asharudin. (2016), "Analisis Harga Pokok Penjualan pada Laba di Apotik Kimia Farma No.66 Luwuk". Jurnal Ekonomi, Fakultas Ekonomi Universitas Muhammadiyah Luwuk. Vol. XXI, No.01

Widyawati, (2013) Akuntansi Biaya, Jakarta

Selatan,; Salemba Empat

Widyawati,(2013), "Analisis Perhitungan Harga Pokok Produksi dan
Penerapan Metode Mark Up dalam Penentuan Harga Jual Produk pada Usaha Amplang di Samarinda", Jurnal Administrasi Bisnis , Fakultas Ilmu Sosial dan Politik Universitas Mulawarman Samarinda. Vol.I No. 2.

Yin, Robert K, (2011), Studi Kasus (Desain dan Motode). PT. Raja Grafindo Persada, Jakarta.

Edvinawidya,https://www.kompasiana.co $\mathrm{m} / \mathrm{edvi}$ nawidya/56408e679493732c048b45 69/ada-apa- dengan-laba-dan-hargapokok-penjualan Diakses tanggal (26 April 2019)

Sitirismaini.blogspot.com/2012/04/analisis perubahan laba kotor.html?m=1. Diakses tanggal 28 April 2019 